\title{
RELATIVE AERIAL BIOMASS YIELD OF INTERCROPPED ALFALFA WITH WINTER FORAGE CEREALS
}

\author{
Telmo Pereyra ${ }^{1}$, Héctor Pagliaricci ${ }^{1}$, and Alfredo Ohanian ${ }^{1}$
}

\begin{abstract}
A B S T R A C T
In the tropical regions of the world, intercropping is mostly associated with food grain production, whereas it is receiving increased attention in temperate regions as a means of efficient forage production. The aim of this work was to determine the relative yield of aerial biomass in alfalfa or lucerne (Medicago sativa L.) and winter forage cereals intercrops. These were done in eight systems resulting from the combination of species sown at different dates. The biomass was measured in three situations: alfalfa and cereal sole-crop and alfalfa-cereal intercrops, the relative biomass yields were calculated by the relative yield index (RYI). The field experiment was conducted as a bifactorial array in a randomized complete block design of two replicates. The alfalfa-cereal intercrops provided RYI values ranging from 0.71 to 0.83 . This showed that it is possible to produce, in the same area, between 71 and $83 \%$ of the biomass that both crops would produce in separate ones.
\end{abstract}

Key words: intercrops, lucerne, winter forage cereals, relative aerial biomass yield, Medicago sativa.

\section{INTRODUCTION}

The yearly forage offer in the center of the southern region of the Province of Córdoba, Argentine, is characterized as very variable due to annual climate conditions and environmental differences among zones, but the most noticeable feature refers to the seasonal variations: the high concentration of forage in spring represents over $75 \%$ of the yearly forage offer (Pagliaricci et al., 1987). It was thought that perennial gramineae of temperate origin could be a solution to this problem. However, low temperatures and high humidity affect the winter growth of these species (Larrea, 1981) and cause serious persistence problems (Pagliaricci et al., 1997).

For this type of problem, there is no doubt that the incorporation of winter forage cereals constitutes a mandatory condition to keep up productivity levels during the winter months. However, in mixed production systems, the competition between agriculture and livestock raising makes it necessary to limit to the utmost the surface intended for annual winter crops, as these compete strongly for the use of the land with agricultural crops, due to the long occupancy period of the lots from the time of election and preparation until the time of the first utilization (Pereyra, 2004).

The rise in minimum tillage practices for the production of grains, cereals and oleaginous species and the advances in the implantation of pastures and winter forage cereals justify the use of this technique. Tomasone $e t$ al. (1996) indicate that the advantages of direct sowing of winter cereals are the possibility to sow at optimum times and with some independence from the rains, minimizing the problems of formation of a superficial

\footnotetext{
${ }^{1}$ Universidad Nacional de Río Cuarto, Facultad de Agronomía y Veterinaria, Ruta 36 km 601, Río Cuarto (CP 5800), Córdoba, Argentina. E-mail: tpereyra@ayv.unrc.edu.ar *Corresponding author.

Received: 1 August 2007.

Accepted: 27 December 2007.
} 
crust and allowing the use of the sowing machinery; it is also possible to anticipate the first utilization due to a better roots anchorage of the plants.

Fernández et al. (1997) pointed out the economic advantages offered by intercropping annual forage species with perennial species. This system also represents a contribution to ecological sustainability due to lesser work and herbicides requirements and the efficient use of the soil.

Anil et al. (1998) indicated that there is a growing interest in the joint cultivation of two or more species - generally known as intercropping - so as to improve the livestock's feed. They also pointed out that species that grow together can be more productive than when growing alone, due to benefits associated to the use of light, the suppression of weeds and the increase of resistance to pests and diseases among others.

The objective of this work was to determine the relative yield of aerial biomass of inter-cropping of alfalfa with winter forage cereals, as compared to monocrop of alfalfa and cereals, in three sowing dates.

\section{MATERIALS AND METHODS}

The experiment was carried out at the Campo Experimental Pozo del Carril (32 $2^{\circ} 58^{\prime}$ S; 6440' W) of the Faculty of Agronomy and Veterinary Studies of the Universidad Nacional de Río Cuarto, sited in the locality of La Aguada, Córdoba, Argentine. This is located in the zone of softly undulating topography of the Department of Río Cuarto, East of the Sierra de Comechingones mountain range.

The predominant climate is temperate with a dry season, a monsoon type precipitation regime, and a dry winter. The mean temperature of the hottest month (January) is $23.3^{\circ} \mathrm{C}$ and that of the coldest month (July) is $8.8^{\circ} \mathrm{C}$, while the frosts-free period lasts for over six months. The soils are located on a softly undulating topography with a slope showing a gradient of 2 to $3 \%$ to the west. The soil is a Typic Hapludoll, coarse silty, thermic (Becker 2000).

In order to evaluate biomass production, two conditions were established in a surface of 2 ha: an area without alfalfa, where pure forage cereals were sown and evaluated, and another with alfalfa on its second year of implantation in which the forage cereals were intersown, establishing the alfalfa-cereal crop. The alfalfa used was $\mathrm{cv}$. Trifecta, grade 8 winter rest, sown in the fall of 2000 with seeds dose of $12 \mathrm{~kg} \mathrm{ha}^{-1}$.

The sowing density of cereals was that necessary to obtain 200 plants $\mathrm{m}^{-2}$. The species and cultivars of winter forage cereals employed were: short cycle oats (Avena sativa L.) cv. Buck tambera (Acc), short cycle barley (Hordeum vulgare L.) cv. Uñaiche INTA $(\mathrm{Cb})$, and triticale ( $\times$ Triticosecale Wittmack) cv. Quiñé-UNRC (Tr), long cycle oats (Avena byzantina K. Koch) cv. Millauquén-INTA (Acl).

Three sowing dates were programmed for intercropping and monocropping cereals: early, 27 February 2001 (Te); intermediate, 31 March 2001 (In); and late 6 May 2001 (Ta).

Eight intercropping systems (SI) were established combining the species and cultivars of forage cereals and the different sowing dates: 1) Alfalfa-short cycle oats, early sowing (Alf-Acc Te); 2) Alfalfa-barley early sowing (Alf-Cb Te); 3) Alfalfa-short cycle oats intermediate sowing (Alf-Acc In); 4) Alfalfa-barley intermediate sowing (Alf-Cb In); 5) Alfalfa-triticale intermediate sowing (Alf-Tr In); 6) Alfalfa-long cycle oats intermediate sowing (Alf-Acl In); 7) Alfalfatriticale late sowing (Alf-Tr Ta); and 8) Alfalfa-long cycle oats late sowing (Alf-Acl Ta).

The area of each plot was $625 \mathrm{~m}^{2} ; 12$ samples per treatment were collected for the determination of the aerial biomass, from an area of $0.25 \mathrm{~m}^{2}$ cut at the height of $10 \mathrm{~cm}$. The sampling frequency was determined by the phenologic stages; in the case of alfalfa, at $10 \%$ flowering and for cereals to the tillering in a vegetative condition and average height of the apexes of 5 to $7 \mathrm{~cm}$ in the reproductive stage. The yield in aerial biomass of monocrops was obtained from the samples and the alfalfa and cereal components were separated in the intercropping plots. All the material collected was dried at $110^{\circ} \mathrm{C}$ in a forced draft oven until reaching constant weight. After sampling the plots were grazed with cattle, using high stocking rates to remove the biomass, thus incorporating the animals as defoliant.

The variable measured was the aerial biomass yield $(\mathrm{kg}$ $\mathrm{MS} \mathrm{ha}^{-1}$ ) of the intercrops and the monocrops of cereal and alfalfa, which were indicated as: $\mathrm{C}_{\mathrm{i}}$ : biomass yield $(\mathrm{kg}$ MS ha-1) of the cereal in intercrop; $\mathrm{C}_{\mathrm{p}}$ : biomass yield ( $\mathrm{kg}$ $\mathrm{MS} \mathrm{ha}^{-1}$ ) of the cereal in monocrop; Alf $_{\mathrm{i}}$ : biomass yield $\left(\mathrm{kg} \mathrm{MS} \mathrm{ha}^{-1}\right)$ of the alfalfa in intercrop; Alf $\mathrm{p}$ : biomass yield $\left(\mathrm{kg} \mathrm{MS} \mathrm{ha}^{-1}\right)$ of alfalfa in monoculture. 
The following indexes defined by Trenbath (1976), were built of the basis of these values:

a) Relative yield of the intercrop (RRI)

$$
\mathrm{RRI}=1 / 2\left(\mathrm{C}_{\mathrm{i}} / \mathrm{C}_{\mathrm{p}}+\mathrm{Alf}_{\mathrm{i}} / \mathrm{Alf}_{\mathrm{p}}\right)
$$

This index allowed knowing the difference in biomass production when alfalfa and cereal are intercropped as compared to the yields of their respective monocrops.

b) Relative yield of the intercropping as related to pure alfalfa (RRI/Alf)

$$
\mathrm{RRI} / \mathrm{Alf}=\left(\mathrm{C}_{\mathrm{i}}+\mathrm{Alf}_{\mathrm{i}}\right) / \mathrm{Alf}_{\mathrm{p}}
$$

This index allowed to ascertain the relationship between the biomass productions of an alfalfa intercrop with cereal as related to alfalfa monocrop, and also to determine if the inter-sowing of cereal improved the production of pure alfalfa.

The treatments were intercropping systems (SI) composed by eight factors, in an experimental design of randomized complete blocks with two replications (Montgomery, 1991).

When the variance analysis showed significant difference in the $\mathrm{F}$ values, the means for the intercropping systems were compared using the Duncan test $(\mathrm{p} \leq 0.05)$. Orthogonal contrasts were carried out (Montgomery, 1991) to observe the effect of the different inter-sowing dates and different species tested, and analyze the differences among early, intermediate and late sowing dates, and the differences among species having difference cycles for the same sowing date.

\section{RESULTS AND DISCUSSION}

The intercropping systems were compared by means of indexes built with yearly biomass yield values $\left(\mathrm{t} \mathrm{MS} \mathrm{ha}{ }^{-1}\right)$ measured in alfalfa and cereal in situation of intercropping and monocrop of both components (Table 1).

\section{a) Relative yield of the intercropping (RRI)}

The intercropping systems (SI) affected the RRI value significantly $(p \leq 0.05)$ (Table 2$)$. The SI that combined late sowing with long cycle species differed significantly $(p \leq 0.05)$ from intermediate sowing SI's. The early sowing SI's did not differ from any of the combinations of late and intermediate sowing (Table 2).

The RRI obtained allowed to establish that the combination of short cycle cereals in early sowing dates and those of long cycle in late sowing, had a greater relative biomass production yield: 0.71 and 0.83 respectively. This was mainly due to the fact that the productions of cereal biomass in situations of intercrop and monocrop did not show a wide difference, as did occur in the intermediate sowing intercropping (Table 1); therefore one of the terms forming this index had a higher relative value closer to the unit in these two situations. For the year of the assay, the values show that it is possible, in the same area, to produce between 71 and $83 \%$ of the forage that could be obtained in pure crops of alfalfa and forage cereals in different areas;

Table 1. Annual biomass yield of forage cereals and alfalfa in intercropping and monocropping. Year 2001. La Aguada, Córdoba, Argentina.

\begin{tabular}{lccc}
\hline \multicolumn{1}{c}{ Intercropping systems } & Cereal intercropping & Pure cereal & Alfalfa in intercropping \\
\cline { 2 - 4 } & $1.68 \pm 0.31$ & t MS ha $^{-1}$ & \\
1. Alf-Acc Te & $1.81 \pm 0.41$ & $2.36 \pm 0.37$ & $4.59 \pm 0.21$ \\
2. Alf-Cb Te & $1.60 \pm 0.21$ & $2.10 \pm 0.73$ & $4.55 \pm 0.52$ \\
3. Alf-Acc In & $1.74 \pm 0.38$ & $2.53 \pm 0.60$ & $3.98 \pm 0.21$ \\
4. Alf-Cb In & $1.45 \pm 0.30$ & $2.62 \pm 0.12$ & $4.18 \pm 0.70$ \\
5. Alf-Tr In & $1.42 \pm 0.47$ & $2.50 \pm 0.36$ & $3.35 \pm 0.24$ \\
6. Alf-Ac1 In & $1.80 \pm 0.34$ & $2.25 \pm 0.67$ & $3.80 \pm 0.50$ \\
7. Alf-Tr Ta & $1.01 \pm 0.49$ & $1.72 \pm 0.25$ & $3.26 \pm 0.46$ \\
8. Alf-Ac1 Ta & n.c. & $1.30 \pm 0.27$ & $4.47 \pm 0.28$ \\
Pure alfalfa & n.c. & 5.50 \\
\hline
\end{tabular}

1. Alfalfa and short cycle oats early sowing; 2 . Alfalfa and barley early sowing; 3 . Alfalfa and short cycle oats intermediate sowing; 4 . Alfalfa and barley intermediate sowing; 5 . Alfalfa and triticale intermediate sowing; 6 . Alfalfa with long cycle oats intermediate sowing; 7 . Alfalfa and triticale late sowing; and 8. Alfalfa and long cycle oats late sowing.

n.c.: Does not apply. 
this would allow opening livestock-raising surfaces to agriculture in the Argentinean Pampas region.

Lanini et al. (1999) in alfalfa inter-sown with oats in Santa Inez, California, USA, informed that the biomass values of the components of the intercropping exceeded those obtained in monocrops of alfalfa and oats by $70 \%$.

On the other hand, Schmidtke et al. (2004) obtained relative indexes, calculated with production of grain in intercropping with lentils (Lens culinaris Medik.) and barley that did no rise above $65 \%$ of the production of the monocrops of both.

\section{Effect of the cereal sowing date on the RRI}

Significant differences were observed $(p \leq 0.05)$ when the intermediate and late sowing dates, as well as the late and early sowing with intermediate were contrasted (Table 3). These differences appeared because the relationship between the productions of cereal in intercropping and monocrop were affected by the sowing date. The contrast between early and late sowing dates did not show significant differences.

The RRI include the addition of two terms, for this reason their variations can give results that do not show differences.

Pagliaricci et al. (1994), working with different sowing dates of winter cereals at Río Cuarto, found that the total production differed statistically when early and late sowing dates were compared. The relationship between the biomass produced by the cereal in intercropping was

Table 2. Relative yield of intercropping (RRI) of alfalfa with winter forage cereals for eight systems. Year 2001. La Aguada, Córdoba, Argentina.

\begin{tabular}{ll}
\hline Intercropping system (SI) & RRI \\
\hline 1. Alf-Acc Te & $0.78 \mathrm{ba}$ \\
2. Alf-Cb Te & $0.78 \mathrm{ba}$ \\
3. Alf-Acc In & $0.73 \mathrm{~b}$ \\
4. Alf-Cb In & $0.74 \mathrm{~b}$ \\
5. Alf-Tr In & $0.71 \mathrm{~b}$ \\
6. Alf-Ac1 In & $0.72 \mathrm{~b}$ \\
7. Alf-Tr Ta & $0.83 \mathrm{a}$ \\
8. Alf-Ac1 Ta & $0.82 \mathrm{a}$ \\
CV, \% & 5.57 \\
Probability & 0.004 \\
\hline
\end{tabular}

Means with different letters differ statistically according to Duncan's test $(\mathrm{p} \leq 0.05)$.

$\mathrm{CV}$ : variation coefficient. similar to that of monocrop in early and late sowings; this would indicate that in those growing periods of the cereal the alfalfa did not compete or else there was some inter-specific interaction which favored the growth of the cereal.

\section{Effect of the species on the RRI}

The results obtained when the cereals were compared among themselves for the same growth cycle, showed that these did not significantly affect the RRI value $(p \geq 0.05)$ both in early and late sowings. The same behavior was observed with short cycle oats and barley in intermediate sowing, however triticale differed significantly ( $p \leq$ 0.05 ) from long cycle oats in the same date, with RRI values for oats higher than those observed for triticale, 0.721 and 0.641 , respectively (Table 4).

When the analysis considered the comparison between species of different cycle for the intermediate sowing date, significant differences were observed $(p \leq 0.05)$ in favor of the short cycle cereals: 0.730 versus 0.681 . Méndez et al. (2001) working with different species and cultivars of winter forage cereals at General Villegas, Argentina, with a single sowing date, did not find differences among the total annual biomass production of oats cv. Cristal-INTA and barley cv. Uñaiché-INTA, both short cycle cultivars.

These results show that within the same sowing date there are no differences among the cereal species evaluated, provided their growth cycles are similar, as the RRI values observed for the intercrops with alfalfa were similar.

Table 3. Sowing date of the cereal effect on the relative yield of intercropping (RRI), alfalfa and cereal. Year 2001. La Aguada, Córdoba, Argentina.

\begin{tabular}{lcc}
\hline Contrast & RRI & Probability \\
\hline Early sowing & 0.784 & \\
Late sowing & 0.815 & $\mathrm{~ns}$ \\
& & \\
Early sowing & $0.784 \mathrm{a}$ & \\
Intermediate sowing & $0.725 \mathrm{~b}$ & 0.0044 \\
& & \\
Intermediate sowing & $0.725 \mathrm{~b}$ & \\
Late sowing & $0.815 \mathrm{a}$ & 0.0020 \\
\hline
\end{tabular}

Means with different letters differ statistically $(\mathrm{p} \leq 0.05)$. ns: non-significant differences. 


\section{Relative yield of the alfalfa-cereal intercrop (RRI) as compared to the alfalfa monocrop (RRI/Alf)}

The SI which combined short cycle species with early sowing date differed statistically $(p \leq 0.05)$ from the SI of long cycle species with late sowing dates (Table 5). The values obtained for the RRI/Alf in the first case, show that the production of the intercropping exceeded that of the alfalfa monocrop, showing that in the intercropping situation the biomass production was $17 \%$ higher than that of pure alfalfa. Heinrichs and Fancelli (1999) using an intercrop of oats and Vicia sativa $\mathrm{L}$., found relative biomass production values between 1.13 and 1.15 .

The same authors concluded that from the production point of view, intercropping increased biomass production by 13 to $15 \%$ and improved the quality of forage due to the nitrogen input of the leguminous. In the same manner, Laborde et al. (2004) at Bahía Blanca in the Argentine, reported for the intercropping of alfalfa and weeping lovegrass (Eragrostis curvula (Schrad.) Nees) the value of 1.36 of relative biomass yield between the association and the alfalfa monocrop.

The RRI/Alf values did not differ statistically between themselves $(p \geq 0.05)$ and the values obtained were near the unit for the SI combining short and long cycle species in intermediate sowing dates. This indicates

Table 4. Effect of cereal species on the relative yield of intercropping (RRI) alfalfa and cereal. Year 2001. La Aguada, Córdoba, Argentina.

\begin{tabular}{lcc}
\hline Contrast & RRI & Probability \\
\hline Early sowing & & \\
$\quad$ Short cycle oats & 0.774 & \\
$\quad$ Barley & 0.776 & $\mathrm{~ns}$ \\
Intermediate sowing & & \\
$\quad$ Short cycle oats & 0.725 & \\
$\quad$ Barley & 0.735 & $\mathrm{~ns}$ \\
$\quad$ Triticale & $0.641 \mathrm{~b}$ & \\
$\quad$ Long cycle oats & $0.721 \mathrm{a}$ & 0.021 \\
$\quad$ Short cycle cereals & $0.730 \mathrm{a}$ & \\
$\quad$ Long cycle cereals & $0.681 \mathrm{~b}$ & 0.041 \\
Late sowing & & \\
$\quad$ Triticale & 0.822 & \\
$\quad$ Long cycle oats & 0.817 & $\mathrm{~ns}$ \\
\hline
\end{tabular}

Means with different letters differ statistically $(\mathrm{p} \leq 0.05)$. ns: Non-significant differences. that the intercropping did not increase the total biomass production above what would be obtained from alfalfa monocropping.

The SI which combined long cycle species in late sowing dates show a behavior similar to those analyzed previously; in both cases the RRI/Alf was below the unit, which indicates that the intercropping produced less total biomass than the alfalfa monocrop.

\section{Effect of the sowing date on the RRI/Alf}

The contrasts carried out to compare the effect of sowing dates on the RRI/Alf showed significant differences $(p \leq 0.05)$ between early and late sowing, as well as between intermediate and late, but there were no differences between early and intermediate sowing (Table 6).

The total production of alfalfa-cereal was greater than that of pure alfalfa only in the early and intermediate sowing dates, where relative yield results exceeded the unit: 1.142 and 1.069 , respectively.

In this respect, Vergara (1996) working on intercropping of wheat (Triticum aestivum L.) and pastures of alfalfa and red clover (Trifolium pratense L.) at Balcarce, Argentine, with two sowing dates, concluded that early sowing of wheat showed comparative advantages in the intercropping biomass production as compared to late sowing.

Table 5. Relative yield of the intercropping (alfalfacereal) in relation to alfalfa monocropping (RRI/ Alf), for eight systems. Year 2001. La Aguada, Córdoba, Argentina.

\begin{tabular}{ll}
\hline Intercropping system & RRI/Alf \\
\hline 1. Alf-Acc Te & $1.17 \mathrm{a}$ \\
2. Alf-Cb Te & $1.12 \mathrm{ba}$ \\
3. Alf-Acc In & $1.09 \mathrm{cba}$ \\
4. Alf-Cb In & $1.11 \mathrm{cba}$ \\
5. Alf-Tr In & $0.97 \mathrm{dcb}$ \\
6. Alf-Ac1 In & $1.00 \mathrm{dcb}$ \\
7. Alf-Tr Ta & $0.93 \mathrm{~d}$ \\
8. Alf-Ac1 Ta & $0.96 \mathrm{dc}$ \\
CV, \% & 8.28 \\
Probability & 0.030 \\
\hline
\end{tabular}

Means with different letters differ statistically according to Duncan's test $(\mathrm{p} \leq 0.05)$.

$\mathrm{CV}$ : variation coefficient. 
Table 6. Sowing date effect on the relative yield of intercropping in relation to alfalfa monocropping (RRI/ Alf) in eight systems of intercropping (alfalfa-cereal). Year 2001. La Aguada, Córdoba, Argentina.

\begin{tabular}{lcc}
\hline Contrast & RRI/Alf & Probability \\
\hline Early sowing & $1.142 \mathrm{a}$ & \\
Late sowing & $0.943 \mathrm{~b}$ & 0.010 \\
& & \\
Early sowing & 1.142 & \\
Intermediate sowing & 1.069 & $\mathrm{~ns}$ \\
Intermediate sowing & $1.069 \mathrm{a}$ & \\
Late sowing & $0.943 \mathrm{~b}$ & 0.033 \\
\hline
\end{tabular}

Means with different letters differ statistically $(\mathrm{p} \leq 0.05)$.

Ns: non-significant differences.

\section{Effect of the forage cereal species employed on the RRI/Alf}

The contrasts did not show significant differences $(p \geq$ 0.05 ) when the species employed within the same sowing date were compared. However, the comparison between short and long cycle species in intermediate sowing dates showed significant difference (Table 7).

These values show that in early and late sowings, the election of one or the other species did not modify the relationship between the biomass production of the intercropping and that of pure alfalfa, but in intermediate sowings the short cycle cereals showed a better relative behavior as compared to long cycles cereals, with indexes of 1.096 and 0.982 , respectively.

Table 7. Effect of species on the relative yield of intercropping in relation to alfalfa monocropping (RRI/Alf) for eight systems. Year 2001. La Aguada, Córdoba, Argentina.

\begin{tabular}{lcc}
\hline Contrast & RRI/Alf & Probability \\
\hline Early sowing & & \\
$\quad$ Short cycle oats & 1.168 & \\
$\quad$ Barley & 1.114 & $\mathrm{~ns}$ \\
Intermediate sowing & & \\
$\quad$ Short cycle oats & 1.089 & \\
$\quad$ Barley & 1.104 & $\mathrm{~ns}$ \\
$\quad$ Triticale & 0.964 & \\
$\quad$ Long cycle oats & 1.000 & $\mathrm{~ns}$ \\
$\quad$ Short cycle cereals & $1.096 \mathrm{a}$ & \\
$\quad$ Long cycle cereals & $0.982 \mathrm{~b}$ & 0.039 \\
Late sowing & & \\
$\quad$ Triticale & 0.931 & \\
$\quad$ Long cycle oats & 0.934 & $\mathrm{~ns}$ \\
\hline
\end{tabular}

Means with different letters differ statistically $(p \leq 0.05)$. ns: non-significant differences.

\section{CONCLUSIONS}

- The intercropping of alfalfa and forage cereal produces between 71 and $83 \%$ of the sum of the biomass obtained by the alfalfa and cereal cultivated alone.

- The biomass production of the cereals in intercropping situations did not exceed in any case that produced by pure cereal cultures.

- The results obtained show that the highest dry matter yields of alfalfa and cereal in the intercroppings occur when using early and intermediate sowing dates and short cycle cereals.

- The interactions of the components of alfalfa-winter forage cereal showed competitive effects, since in no case the relative yield did exceed the unit. The nature of the interactions depends on the sowing date of the cereals and their growth cycles.

- The relative yield on the intercropping as compared to pure alfalfa shows that early sowing dates and short cycle cereals improve total production as compared to alfalfa monocrops.

\section{R E S U M E N}

Rendimiento relativo de biomasa aérea en intercultivos de alfalfa con cereales forrajeros de invierno. Telmo Pereyra $^{1^{*}}$, Héctor Pagliaricci ${ }^{1}$, y Alfredo Ohanian ${ }^{1}$. En las regiones tropicales del mundo, el intercultivo está asociado con la producción de granos para la alimentación, mientras que en áreas templadas recibe mayor atención como medio de producción eficiente de forraje. El objetivo de este experimento fue determinar el rendimiento relativo de biomasa aérea en intercultivos de alfalfa (Medicago sativa L.) y cereales forrajeros de invierno. Se establecieron ocho sistemas producto de la combinación con especies de cereales con distintas fechas de siembra. Las mediciones de biomasa se realizaron en tres situaciones: monocultivo de alfalfa, monocultivo de cereales e intercultivo de alfalfa-cereal, calculándose el rendimiento relativo del intercultivo (RRI). Se empleó un diseño con arreglo bifactorial y dos repeticiones en bloques completos al azar. Los intercultivos de alfalfa-cereal generaron valores de RRI entre 0,71 y 0,83 , lo que indicó que en una misma superficie es posible producir entre el 71 y $83 \%$ de la biomasa que ambos cultivos producirían en superficies separadas.

Palabras clave: intercultivos, alfalfa, cereales forrajeros de invierno, rendimiento relativo de biomasa, Medicago sativa. 


\section{LITERATURE CITED}

Anil, L., J. Park, R. H. Phipps, and F. A. Muller. 1998. Temperate intercropping of cereals for forage: a review of the potential for growth and utilization with particular reference to the UK. Grass and Forage Science 53:301-317.

Becker, A. 2000. Evaluación del proceso de degradación en suelos por erosión hídrica en una subcuenca representativa de la región pedemontana del suroeste de la provincia de Córdoba, Argentina. 422 p. Tesis Doctorado en Ciencias Geológicas. Universidad Nacional de Río Cuarto, Río Cuarto, Córdoba, Argentina.

Fernández, O.N., P. Vergara, O.R. Vignolo, y P. Laterra. 1997. Producción de una pastura polifítica en siembra consociada con verdeos de invierno. Rev. Arg. Prod. Anim. 17:96-101.

Heinrichs, R., and A.L. Fancelli. 1999. Influence of intercropped common vetch (Vicia sativa L.) and naked oat (Avena strigosa) on biomass production and nitrogen addition. Scientia Agricola 56:56-70.

Laborde, H., H. Arelovich, R. Brevedan, S. Canalo, y J. Oyola. 2004. Rendimiento de forraje de cultivos puros y asociados de pasto llorón, digitaria y alfalfa con diferentes arreglos espaciales. Rev. Arg. Prod. Anim. 4:57-62.

Lanini, W.T., S.B. Orloff, W.E. Bendixen, W.M. Canevari, J.L. Schmierer, and R.N. Vargas. 1999. Influence of oat (Avena sativa L.) interseeding on weed suppression in the final year of an alfalfa (Medicago sativa) stand. Weed Technol. 13:399-403.

Larrea, D. 1981. Los pastos de invierno en los planes de producción forrajera de la región pampeana semiárida 21 p. Instituto Nacional de Tecnología Agropecuaria (INTA), Estación Experimental Agropecuaria Bordenave, Bordenave, Argentina.

Méndez, D., P. Davies, A. Zamolinski, y O. Peralta. 2001. Evaluación de especies y cultivares de cereales de invierno para pastoreo en el área de la EEA General Villegas INTA. Rev. Arg. Prod. Anim. 22(Sup. 1):217-218.

Montgomery, D.C. 1991. Diseño y análisis de experimentos. 34 p. Grupo Editorial Iberoamericana, México.
Pagliaricci, H., A. Ohanian, R. Fantino, y C. Saroff. 1987. Producción, distribución estacional e intervalo entre pastoreos en pasturas consociadas. p. 53. II Jornadas Científico-Técnicas de la Facultad de Agronomía y Veterinaria de la Universidad Nacional de Río Cuarto, Argentina. Acta de Resúmenes. 3-6 de junio de 1987. Universidad Nacional de Río Cuarto, Río Cuarto, Argentina.

Pagliaricci, H., A.E. Ohanian, S. González, y T. Pereyra. 1997. Producción de verdeos de invierno en Río Cuarto en 1995. Información para extensión $\mathrm{N}^{\circ} 43$. 16 p. Instituto Nacional de Tecnología Agropecuaria (INTA), Estación Experimental Agropecuaria Marcos Juárez, Marcos Juárez, Argentina.

Pagliaricci, H.R., A.C. Saroff, A.E. Ohanian, S. González, y T. Pereyra. 1994. Producción y distribución de forraje en verdeos de invierno con dos fechas de siembra. Rev. UNRC 14:5-11. Universidad Nacional de Río Cuarto, Argentina.

Pereyra, T. 2004. Producción de forraje de alfalfa (Medicago sativa L.) intersembrada con cereales forrajeros de invierno. Tesis de Magíster Scientiae. Facultad de Agronomía y Veterinaria, Universidad Nacional de Río Cuarto, Córdoba, Argentina.

Schmidtke, K., A. Neumann, C. Hof, and R. Rauber. 2004. Soil and atmospheric nitrogen uptake by lentil (Lens culinaris Medik.) and barley (Hordeum vulgare ssp. nudum L.) as monocrops and intercrops. Field Crops Res. 87:245-256.

Tomasone, F., J.L. Rey, T. Trossero, y R. Kuhlman. 1996. Pasturas y verdeos en siembra directa. Actas IV Congreso Nacional de Siembra Directa, Rosario, Argentina. 10-13 de agosto de 1996. Asociación Argentina de Productores en Siembra Directa (AAPRESID) 2:154-166.

Trenbath, B.R. 1976. Intercropping for the management of pests and diseases. Field Crops Res. 34:381-405.

Vergara, P.A. 1996. Producción de pasturas en siembras consociadas con cereales de invierno. 219 p. Tesis Ingeniero Agrónomo. Universidad Nacional de Mar del Plata, Facultad de Ciencias Agrarias, Mar del Plata, Argentina. 